\title{
Capital account regulation as part of the macroeconomic regime: comparing Brazil in the 1990s and 2000s*
}

\author{
Barbara Fritz ${ }^{* *}$ \\ Professor of Economics, Institute for Latin American Studies, Freie Universität Berlin, Germany \\ Daniela Magalhães Prates*** \\ Associate Professor of Economics, University of Campinas, Unicamp, Brazil and CNPq researcher
}

Capital account regulation (CAR) has experienced profound reconsideration since the global financial crisis. This new debate focuses on the macroeconomic gains of regulating international capital flows in terms of reducing external and financial vulnerability, but it does not consider relevant aspects relating to the context in which these regulations are implemented. In this paper, we undertake a comparative analysis of similar types of CAR applied in Brazil during the 1990s and 2000s. Based on this analysis, we conclude that for the design of CAR, which is relevant for its effectiveness, institutional features of both the financial market and the macroeconomic regime, shaped by macroeconomic constraints, are relevant. For the case of Brazil, we conclude that, contrary to the 2000s, the strong preference given to inflation stabilization in the 1990s, together with high external vulnerability, strongly limited the CAR's design of this period.

Keywords: macroeconomic regime, capital account regulation, capital flows, emerging economies

JEL codes: $E 6, F 3, F 4, F 6$

\section{INTRODUCTION}

The issue of the regulation of international finance garnered greater attention in the years following the global crisis of 2008 than it did before that event. The counter-cyclical monetary policies in advanced economies brought a new wave of high and volatile capital flows to emerging economies. These finally caused a major shift in terms of the perspective on the issue of capital flows. While for a long period a microeconomic perspective on the efficiency of international financial liberalization dominated the debate, recent years have brought a shift towards a macroeconomic perspective. Currently, the focus is on the macroeconomic gains of regulating international capital flows in terms of reducing external and financial vulnerability. The debate mainly centers around the question of whether the regulation of capital flows should be an additional instrument to deal with exceptional times of high and unstable flows, having all other macroeconomic policies

* We thank the anonymous referees and Torsten Niechoj for their valuable comments.

** Email: barbara.fritz@fu-berlin.de.

*** Email: prates@unicamp.br.

Received 25 June 2014, accepted 21 September 2017 
exhausted, or whether these should be redefined as a permanent instrument of the toolkit for emerging economies for reducing macroeconomic vulnerability.

Less attention has been given to the comparability of capital account regulation among different countries and time periods. A closer look shows that we find here a broad variety not only in terms of the specific tools used - which can range from taxes over quantitative controls to verbal persuasion - but also, and no less importantly, in terms of their aims. While some are established with the expectation of making capital flows less short term and less volatile, but no less in terms of volume, others are established to dampen inflows overall, in order to shield the exchange rate or the domestic financial sector from major disequilibria.

Our paper seeks to contribute to this comparative perspective by linking the design of capital account regulation (CAR) to the specific macroeconomic and institutional context it is implemented within. By comparing the application of similar types of CAR in Brazil during the 1990 s and the 2000 s, we ask which variables shape the design of CAR. We assume that the effectiveness of CAR is a consequence of its design. Our hypothesis is that even if institutional features of the financial market matter, which was one of the main conclusions of the empirical studies of the 1990s, the macroeconomic regime, shaped itself by external constraints, is of even greater relevance.

We define the macroeconomic regime as an intermediary concept between global structures and economic policies at the domestic level. Following Herr/Kazandziska (2011: 2) we understand the macroeconomic regime as

the interaction between monetary policy, fiscal policy, wage policy and foreign economic policy within a framework of both: macroeconomic institutions which can be actively changed by policy-makers and become part of economic policy, and institutions which are beyond the control of policy-makers.

In this paper, we will focus on the embeddedness of CAR, specifically within monetary and exchange rate policies, as these are the most interrelated policy fields with the management of international capital flows. Emerging market economies are especially more susceptible to external vulnerability, caused not only by the volatility of export prices and capital flows, but also by the fact that their external debt is mostly denominated in international currency. We argue that the choice of macroeconomic regime is shaped by domestic preferences as well as by the current setting of international constraints.

We will first give an overview on the debate on CAR (Section 2). Second, we present the Brazilian experience in the 1990s (Section 3) and the 2000s (Section 4). Third, we undertake a comparative assessment of the design of CAR implemented in Brazil during those two periods (Sections 5). Finally, we draw some general conclusions (Section 6).

\section{CAPITAL ACCOUNT REGULATION: AN OVERVIEW}

For an astonishingly long time, the dominant position had been to reject capital controls, based on neoclassical welfare theory. From this standpoint, there were three main arguments in favor of liberalized capital flows: First, intertemporal trade - that is, temporary import of savings would allow for intertemporal smoothing of investment and consumption, to be reversed later via an increased volume of produced goods and/or increased productivity (for example, Dooley 1996). Second, given differing capital endowment - poor countries are assumed to be relatively rich in labor relative to domestically available capital, and rich countries are assumed to be the opposite - capital flows from rich to poor countries should allow for the easing of capital constraints in developing economies leading to higher investment and growth rates and reducing the price for capital, that is, to interest rate parity in the long run. It should 
also allow for the international diffusion of new technology (see, for example, World Bank 2001). Third, the international allocation of capital was seen as permitting better risk diversification (Fettig 1996) and the possibility of financing riskier projects. Most studies in this period thus where interested mostly to see whether capital controls were able to lengthen the maturity of capital inflows (for example, De Gregorio et al. 2000; Edwards 1999).

The new wave of capital flows finally brought forward a macroeconomic perspective on the gains of regulating international capital flows in terms of reducing external and financial vulnerability. The turn to a more supporting view was brought forward mostly by the IMF with its new 'institutional view' on capital account liberalization and capital controls (IMF 2012). In this and other related documents (IMF 2011; Ostry et al. 2010), the IMF showed remarkable changes in its approach towards international financial liberalization. It acknowledged that, despite substantial benefits such as enhanced efficiency for receiving countries, rapid capital inflows and disruptive outflows also carry risks, especially when countries have not attained a certain level of financial and institutional development. From this angle, capital controls began to be seen as useful in dealing with the policy challenges of inflow surges and the risk of sudden outflows. In order to avoid the negative connotation of the term 'controls,' the IMF labeled its concept as 'capital flow management measures' (IMF 2011).

One of the major disputes around this new approach was whether these measures should be of a temporary or permanent nature. The IMF concept continued seeing these as an instrument only for especially turbulent times: 'The temporary re-imposition of capital flow management measures under certain circumstances is consistent with an overall strategy of capital flow liberalization' (IMF 2012: 15). Also, these measures were only to be applied temporarily and when macroeconomic policies such as monetary, fiscal, and exchange rate policies were exhausted and sound financial supervision and regulation exercised by strong institutions was in place (ibid.: 19). Others (for example, Gallagher et al. 2012) criticized this approach as being too narrow. First, for not taking into account theoretical and empirical work on the limited effectiveness and risks associated with international financial liberalization. Second, in the view of Gallagher et al., a framework for capital account regulation should enable recipient countries to pursue counter-cyclical policies to shield themselves from global financial shocks and allow them to pursue a macroeconomic policy mix befitting the country's requirements, constituting a permanent part of the economic policy toolkit of developing and emerging market economies. These authors proposed a framework for CAR as an analogy to (also permanent) financial regulation, which should enable recipient countries to pursue counter-cyclical policies in an attempt to both shield themselves from global financial shocks and increase their policy space pursuing a macroeconomic policy mix appropriate to the country's requirements.

Despite the relevance given to this topic, Rodrik (2010: 265) states: 'We currently do not know much about designing capital control regimes. The taboo that has attached to capital controls has discouraged practical, policy-oriented work that would help to manage capital flows directly.' The comparability of different CAR measures has gained much less attention in this debate. It still holds, to a certain degree, to what Magud et al. (2011) call an 'apples-to-oranges problem': most studies, to our knowledge, do not systematically consider heterogeneity in time and space regarding the macroeconomic context.

This heterogeneity can be organized into three main categories, following Magud et al. (ibid.): (i) There is no unified theoretical framework to analyse the macroeconomic consequences of controls in emerging markets, as the debate above shows. (ii) There is great variety in the types of controls: taxes, unremunerated reserve requirements, quantitative restrictions, and verbal persuasion. In view of the sophisticated nature of financial markets, the devil is often in the detail - and what works in one setting is unlikely to work well in others. (iii) Policy-makers implemented the measures based on significantly different aims. 
Capital controls may aim at banning the inflow of 'hot money' by altering the composition of inflows, or at reducing the volume of inflows in order to prevent instability in the domestic financial sector; they may be launched in order to reduce the pressure on the exchange rate, or to make more policy space for an independent monetary policy at the domestic level. Even if these aims are partially interdependent, criteria for the 'success' of capital controls have to be adjusted to case-specific policy goals.

Regarding category (i), we adhere to the use of the concept of CAR since we assume the necessity for emerging economies to reduce the degree of external vulnerability for enhancing their policy space, which requires the permanent management of capital flows (see also Fritz/Prates 2014; Gallagher et al. 2012). In this paper, we thus focus on categories (ii) and (iii), but we add a fourth category, the relevant context variables, which also differ over time and space. We identify three context variables, as explained below.

The first is the current stage of external constraints that, together with the departing conditions of an economy, delimit the choices for a specific macroeconomic regime. Most importantly, net stock of external assets or liabilities and availability of international liquidity define how far a country can afford to repel capital inflows. For the macroeconomic regime, as defined above, we will refer herein to the sum of exchange rate and monetary policies which are directly interrelated with the CAR. Second, the stage and state of the domestic economy, together with the preferences of ruling economic and political actor constellations, will influence the aims, targets, and tools of the macroeconomic regime and thus the policies in different sub-fields. When CAR are adopted, their aims, and consequently targets and tools, will be framed by the aims of the monetary and exchange rate policies that are under way, ${ }^{1}$ shaped by the external constraints. The third variable is domestic institutional aspects that, given the aims defined by the interplay between the first and second variables, will shape the tools of CAR. In the case of Brazil, the main institutional aspects are the level of financial openness and the features of the financial market, which encompass the foreign exchange (FX) market (see Figure 1).

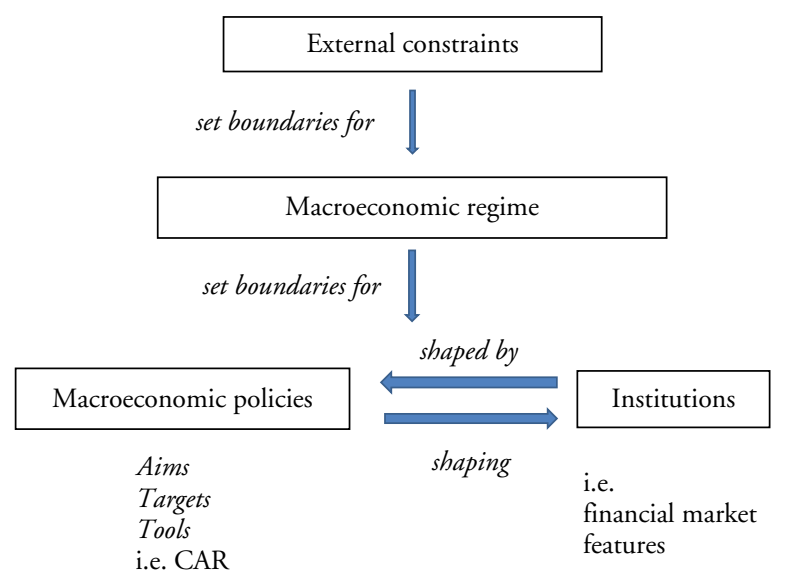

Source: Authors' compilation.

\section{Figure 1 Macroeconomic regime}

1. BIS (2005) adopted the same classification to analyse exchange rate policies of emerging economies. 
Empirically, we compare the aims, targets, and tools of CAR in Brazil during two periods, the 1990s and the 2000s. Methodologically, our analysis is based on descriptive statistics and qualitative evaluation. Very short time periods to be analysed, frequent changes of regulation within these short periods, together with other variable changes such as repeated changes of capital inflow volumes and composition due to exogenous shocks and changes in monetary and exchange rate policies render time series analysis somewhat ineffective. Furthermore, regulations, capital volumes, and composition and monetary policies are highly interdependent. For these reasons, we have opted out of econometric analysis in our comparative case study.

\section{CAPITAL ACCOUNT REGULATION IN BRAZIL: THE CASE OF THE 1990s}

This section starts with a review of the literature on CAR implemented in Brazil during the 1990s that focuses on the effectiveness of this regulation, disregarding the macroeconomic and institutional contexts. Thereafter, we undertake a qualitative assessment of the design of CAR during this period within the macroeconomic regime in force.

\subsection{The literature review}

Reviewing the literature, most studies focus on evaluating the effectiveness of CAR in Brazil during the 1990s. They argue that these were, at best, only efficient in the short term. In their comparative study on capital controls in emerging markets during the 1990s, Ariyoshi et al. (2000: 17) conclude that 'the controls maintained by Brazil appear to have been largely ineffective in achieving their stated object.' Thus, Brazil stands out against other cases analysed in their study, where the inflow controls achieved at least some of their intended objectives (maintaining a suitable wedge between domestic and foreign interest rates and reducing upward pressure on the exchange rate).

Others, such as Cardoso/Goldfajn (1997), Carvalho/Garcia (2006), and Reinhart/ Smith (1998), find that these controls had at least temporary effects, especially on the composition of capital flows, although in the long run capital inflows remained unchanged by capital controls. The main argument brought forward by these studies is the ability of financial actors to circumvent controls due to the elevated sophistication ${ }^{2}$ of the domestic

Table 1 Literature survey: evaluation of effectiveness of 1990s capital controls

\begin{tabular}{lll}
\hline Authors & Reduces volume & Lengthens maturity \\
\hline Ariyoshi et al. (2000) & 0 & 0 \\
Cardoso/Goldfajn (1997) & Short term & Short term \\
Garcia/Barcinski (1997) & $\begin{array}{l}\text { No econometric test; yet find CC } \\
\text { ineffective for reduction of volume }\end{array}$ & - \\
Reinhart/Smith (1998) & Short term & Short term \\
Carvalho/Garcia (2006) & Short term & Short term \\
Williamson et al. (2003) & Short term & Short term \\
\hline
\end{tabular}

Source: Authors' compilation.

2. To our knowledge, there is no established concept of financial market sophistication in the academic literature. The World Bank composes a very ample indicator of financial market sophistication with the following sub-indicators: (i) availability of financial services; (ii) affordability of financial services; (iii) financing through local equity markets; (iv) ease of access to loans; (v) soundness of banks; 
financial sector in Brazil combined with a continuous and substantial interest rate differential, creating a strong motivation to rapidly circumvent the controls.

The main lesson from the Brazilian experience seems to be that the effectiveness of capital controls might be limited in an environment where the sophistication of the financial markets reduces the cost of circumvention relative to the incentives for circumvention. In the long run, repeated attempts by the authorities to restrict capital inflows were unsuccessful, since capital continued to find ways to enter the economy, particularly in view of the persistent incentives provided by interest rate differentials that remained high. (Ariyoshi et al. 2000: 45).

The evaluation of Williamson et al. (2003) points in a similar direction, but with reversed causality: Brazilian capital import controls were limited in their efficiency because the complexity of and frequent changes in the regulations to cope with circumvention strategies had weakened them (see Table 1 on previous page).

\subsection{CAR under conditions of exchange rate anchored stabilization and external vulnerability}

Coming off a lengthy process of rocketing inflation and a profound external debt crisis, Brazil managed to successfully stabilize its currency by using the exchange rate as a nominal anchor in 1994. The so-called Plano Real quickly took inflation down from almost 3000 percent p.a. in 1993 to a level of less than 10 percent p.a. from 1996 onwards. In doing so, it followed the path of a large number of developing and emerging market economies, especially in Latin America and South East Asia, which opted for an exchange rate anchor during the 1990s. The aim was to gain credibility in terms of inflation expectations by clearly prioritizing the maintenance of a predetermined nominal exchange rate level in economic policy strategy. This was supposed to discipline monetary and fiscal policies at the domestic level (for an overview, see Fritz 2000; Singh et al. 2005).

The Brazilian version of the exchange rate anchor was not a radical fixing of the exchange rate (as was the case with neighboring Argentina), but, rather, a fixing of the nominal exchange rate within a crawling band from March 1995 until January 1999. Devaluations of the crawling band ex post appeared to be rather constant ( 0.7 percent p.m.), but were handled discretionarily (Figure 2).

Due to inflation rate differentials that constantly outstripped nominal devaluation, the Brazilian currency significantly appreciated against the rest of the world currencies in real terms. Together with trade liberalization, this real appreciation sharply turned trade flows. The current account, after having shown a slight surplus for some years, experienced sharply increased deficits between 1995 and 1999.

Simultaneously, capital inflows started growing quickly (see Figure 3). This surge was related to the swift inflation stabilization, but there were additional factors: (i) a Brady Plan for Brazil (concluded in April 1994), which finally regularized the country's relations with the international financial community; (ii) sinking international interest rates in response to the advanced countries' recession at the beginning of the 1990s, which

\section{(footnote 2 continued)}

(vi) regulation of securities exchanges; and (vii) legal rights index (see http://worldbank.270a.info/ classification/indicator/GCI.8THPILLAR.XQ.html). Again, for the sake of operationalization, in this paper we adopt a narrow concept of financial market sophistication, which refers to the availability of liquid and deep markets with developed countries' state-of-the art financial innovations, such as financial derivatives. 


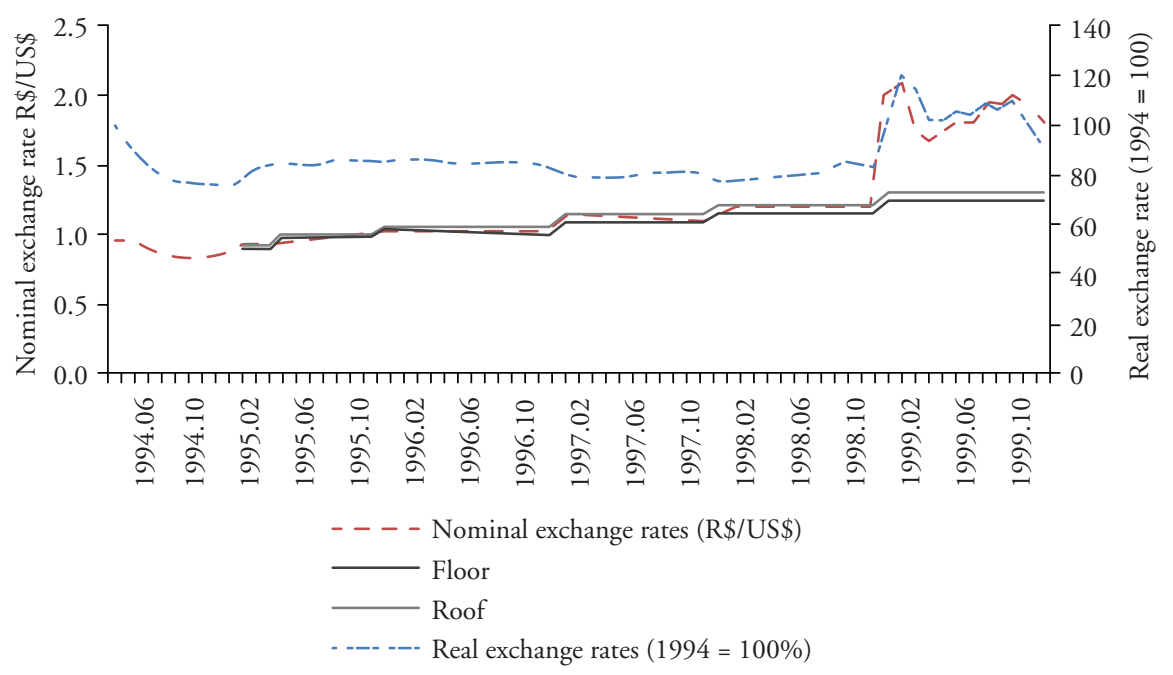

Sources: IPEA data, authors' compilation.

Figure 2 Exchange rate (real and nominal) and exchange rate band (ex post)

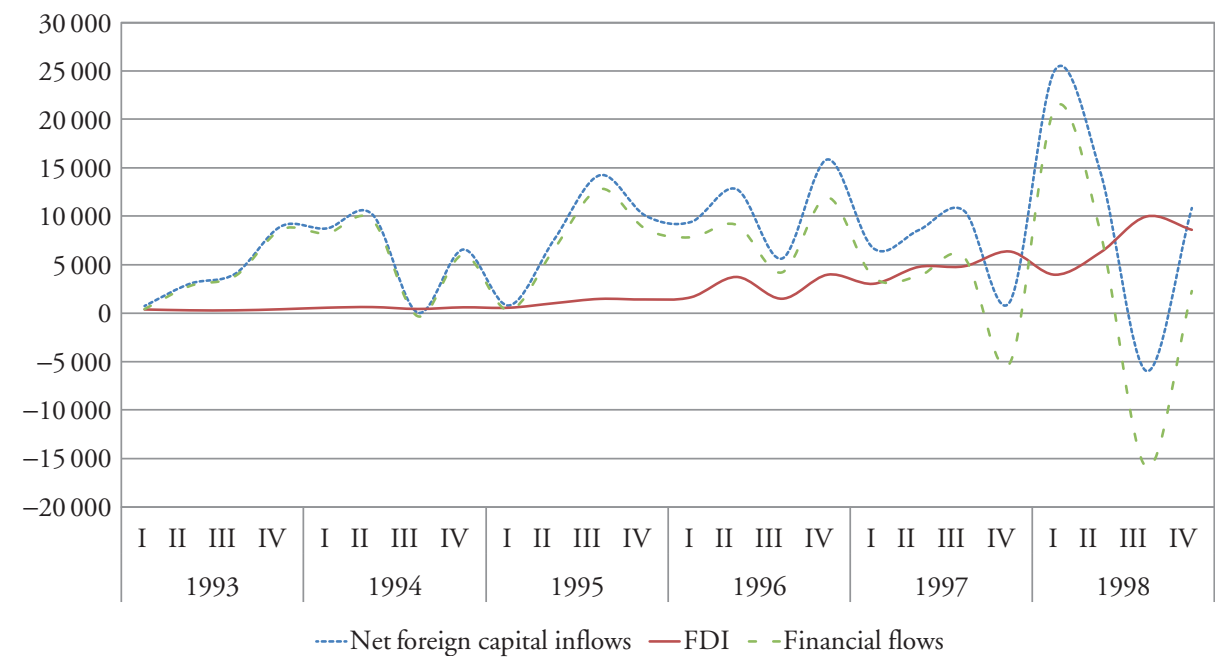

Sources: BCB; authors' compilation.

\section{Figure 3 Net foreign capital inflows, US\$ million}

increased the volume of capital offered to emerging economies (Calvo et al. 1993); (iii) a comprehensive privatization program of Brazilian public firms and banks, where international investors were explicitly invited to participate; and (iv), last but not least, the opening of the Brazilian capital account, which was a precondition for the Real Plan inasmuch 
as it enabled capital inflows and the accumulation of foreign exchange reserves in the period $1990-1993^{3}$ (Paula 2011).

A strong incentive for capital inflows via bank credit and portfolio capital, in particular, was the high interest rate differential. Nominal and real interest rates in Brazil remained at a very high level (see Figure 4), as monetary policy, despite the stabilizing effects of the exchange rate anchor, still had to compensate for only gradually evading inflation expectations and a softened version of exchange rate based inflation stabilization to curb domestic demand and attract capital flows in the face of both the increasing current account deficit and the need to refinance the huge external debt accumulated during the 1970s. Then, besides the still high inflation, the Brazilian economy faced an increasing external vulnerability as macroeconomic constraints, becoming highly sensitive to shifts in the international financial market.

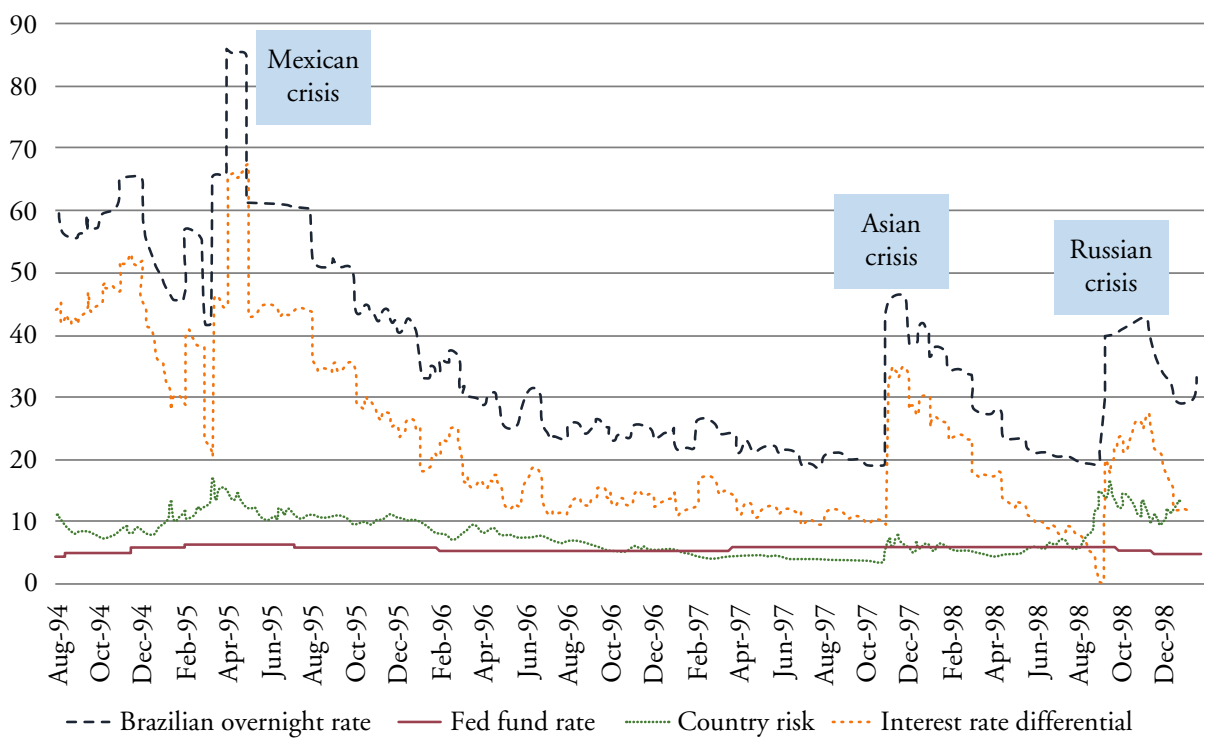

Sources: BCB and Federal Reserve; authors' compilation.

\section{Figure 4 Interest rate differential and its components (\%)}

3. In 1991 and especially in 1992, the Brazilian Central Bank launched a series of measures in order to benefit from capital inflows that had started in 1991. The main measures were: (i) the Brazilian capital market was opened for international portfolio flows inasmuch as the direct acquisition of Brazilian firms' equities by foreign institutional investors was permitted; (ii) foreign investors were also allowed to invest in derivatives markets (limited since 1995 to operations to hedge positions in spot markets, as mentioned below); (iii) firms were allowed to issue new types of securities abroad (such as commercial papers) and securities convertible into stocks; and (vi) the additional income tax on profit and dividend remittance abroad was abolished. Yet, in face of the excessive short term capital inflows, in 1993, some administrative capital controls were adopted: the tax-exempted channel ('Annex IV') for foreign investment funds to go into fixed-yield bonds (especially public bonds) was closed; foreign portfolio investments into debentures (private fixed-yield bonds) were prohibited, and, at the same time, a specific channel for international fixed income (foreign capital fixed yield funds) with a 5 percent financial tax (IOF) was created and a broader range of fixed-income securities, including derivatives and privatization bonds, was prohibited (Paula 2011). 
As a result, the macroeconomic regime had to be conducted primarily in order to ensure capital inflows in sufficient quantity, resulting in a sequence of stop-and-go periods. The definition of the internal interest rate level was highly correlated to the quantity of capital inflows and FX reserves. Every time capital inflows shrank or even reversed due to external shocks, the domestic interest rate had to be hiked in order to both reduce the volume of imports and encourage additional capital inflows (see Figure 5). This led to a stop-go process, due to the repeated necessity of repressing internal demand in order to control external accounts.

During the boom phases of the international capital flow cycle, the high interest rate differential offered by Brazil resulted in excessive short-term financial inflows, above the current account deficit. In these phases, the central bank needed to pursue direct interventions both in the exchange market to control the nominal exchange rate level and in the monetary market through sterilization operations to maintain a restrictive monetary policy, overburdening the fiscal costs of capital inflows. As Kregel (2000: 5) summarized:

[T]he success of the Real Plan was on capital inflows buttressing the nominal exchange rate anchor in the face of rising current account imbalances. The success of the Plan thus made necessary domestic interest rates that were sufficiently high to produce a sufficiently large international interest rate differential to sustain capital inflows ... . The capital inflows in excess of what was required to finance the current account imbalance was countered by sterilisation of the inflows at negative carry that also increased the government deficit and thus outstanding debt.

In the face of the increasing fiscal costs of sterilization operations through emission of public bonds, the Brazilian government chose to adopt capital controls mainly to lengthen the maturity of foreign portfolio investment in the face of the increasing external vulnerability. A secondary aim was to reduce their volume in moments of excessive inflows.

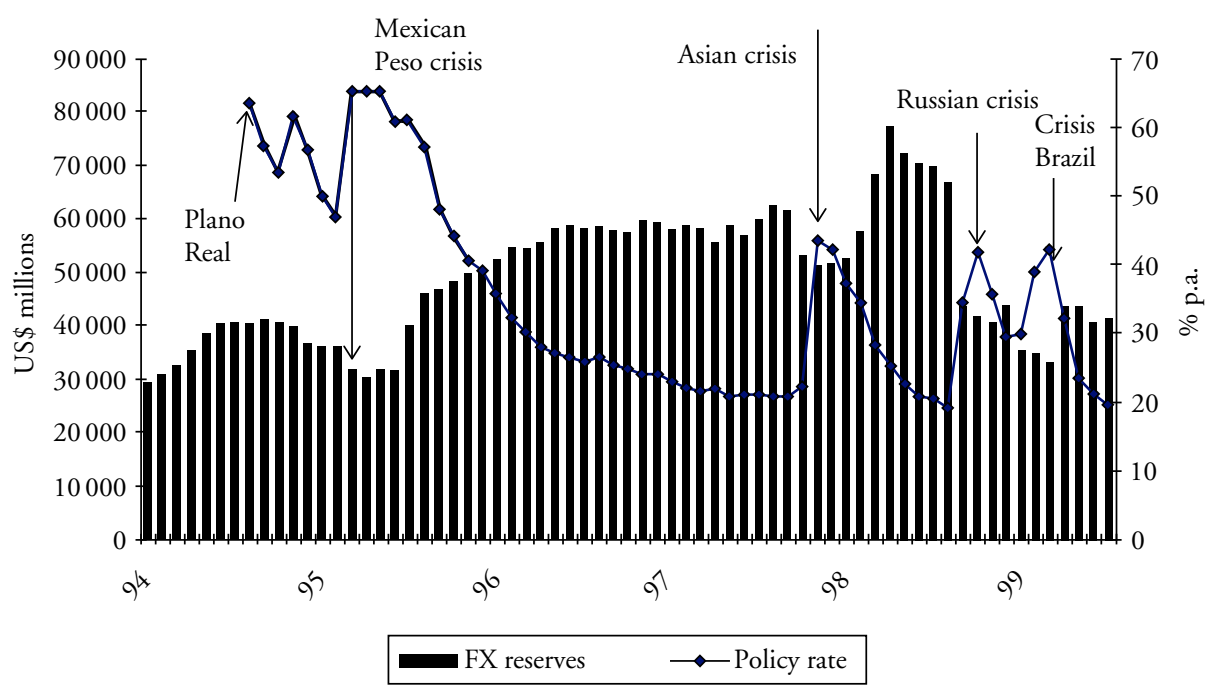

Source: Boletim do Banco Central do Brasil; authors' compilation.

Figure 5 Brazil: domestic interest rate and foreign exchange reserves (1994-1999) 
Thus Brazil joined the small group of emerging countries which applied these controls. From $1993^{4}$ to 1999 , with temporary interruptions due to stop phases within the capital flows cycle, the central bank launched a series of measures meant to discourage short-term capital inflows, principally short-term foreign loans and foreign portfolio investment into the public bond secondary market. These controls took the form of an entry tax, called the Tax on Financial Operations (Imposto sobre Operaçóes Financeiras - IOF), in conjunction with minimum maturity for portfolio investments and administrative controls to close channels for short-term inflows (see Table 2).

Table 2 Capital account regulation, 1994-1998

\begin{tabular}{|c|c|c|}
\hline & $\begin{array}{l}\text { Tighten or } \\
\text { loosen }\end{array}$ & Measure \\
\hline Mar. 1994 & Tighten & $\begin{array}{l}\text { Entrance tax extended to all portfolio investments, although the } \\
\text { initial level at the beginning was set as zero. This was meant as a } \\
\text { 'clear signal as to the possibilities of taxing these operations' } \\
\text { (BCB 1995) }\end{array}$ \\
\hline Oct. 1994 & Tighten & $\begin{array}{l}\text { Entrance tax on most portfolio investments and loans raised: from } \\
5 \% \text { to } 9 \% \text { for investments in Foreign Capital Fixed Yield } \\
\text { Funds; from } 3 \% \text { to } 7 \% \text { in the case of loans; and from } 0 \text { to } 1 \% \text { in } \\
\text { the case of Annex IV investments }\end{array}$ \\
\hline Mar. 1995 & Loosen & $\begin{array}{l}\text { (i) Minimum stay periods, expanded in June } 1993 \text { for certain } \\
\text { types of capital inflows, were reduced } \\
\text { (ii) Entrance tax decreased to pre-October } 1994 \text { levels (and } \\
\text { foreign loans excluded from any entrance taxation) }\end{array}$ \\
\hline Aug. 1995 & Tighten & $\begin{array}{l}\text { (i) The entrance tax re-established for foreign loans (5\%) and } \\
\text { foreign capital fixed yield investment funds (7\%), and } \\
\text { broadened to include the floating-rate segment for short-term } \\
\text { finance between international and national banks (another way } \\
\text { found by the market to circumvent the restrictions) } \\
\text { (ii) Foreign investors access to the derivative markets limited to } \\
\text { hedge operations related with their portfolio investments in } \\
\text { equity and fixed-income bonds }\end{array}$ \\
\hline Sept. 1995 & Tighten & $\begin{array}{l}\text { Entrance tax adopted as a decreasing scale, inversely related to } \\
\text { loan maturity ( } 5 \% \text { for two years or less, } 4 \% \text { for three years, } 2 \% \\
\text { for four years, } 1 \% \text { for five years, and } 0 \% \text { for } 6 \text { years or more) }\end{array}$ \\
\hline Feb. 1996 & Tighten & $\begin{array}{l}\text { (i) Most remaining channels for short-term inflows into fixed } \\
\text { income investments and fixed income-linked strategies } \\
\text { forbidden outright } \\
\text { (ii) Minimum maturity for all currency loans extended to } \\
\text { three years } \\
\text { (iii) Entrance tax to investments in privatization funds extended }\end{array}$ \\
\hline Jul. 1997 & Loosen & $\begin{array}{l}\text { Minimum maturity for all currency loans shortened to one } \\
\text { year and entrance tax reduced }\end{array}$ \\
\hline Aug. 1998 & Loosen & Minimum maturity and entrance taxes reduced. \\
\hline
\end{tabular}

Sources: Garcia/Barcinsky (1997); Blumenschein/Guinle (2001); and Ariyoshi et al. (2000) for the period of 1992-1996. Analysis of changes in capital account regulation for the period 1997-2000 is based on BCB (1999; 2000); AREAER (various issues); Paula et al. (2003); Franco/Pinho (2004).

4. Already in 1993, within the context of substantial exchange market liberalization but still with very high inflation, the government had begun a gradual process of 'throwing sand in the wheels' of short-term capital inflows directed to fixed-income securities. 
Table 3 Brazil, 1990s

Macroeconomic constraints

- External vulnerability: high (high external debt; high current account deficit)

- Inflation: high

\begin{tabular}{l|l}
\hline \multicolumn{2}{c}{ Macroeconomic regime } \\
\hline Macroeconomic policy & Institutions \\
Exchange rate anchored stabilization & \\
Aim: inflation reduction & \\
Target: inflation rate & \\
Tools: & - Financial openness: middle to high \\
- stabilize nominal exchange rate & - Financial market sophistication: middle to \\
- CAR & high (derivatives) \\
Aim: maturity prolongation; sporadically, \\
$\begin{array}{l}\text { volume reduction } \\
\text { Target: capital flow maturity }\end{array}$ \\
$\begin{array}{l}\text { Tools: price-based capital controls (financial } \\
\text { tadministrative controls }\end{array}$ \\
\hline
\end{tabular}

Source: Authors' compilation.

The regulations were adjusted within the stop-go cycle of volatile capital inflows due to financial crisis episodes in other emerging market economies, tightening or loosening depending on the moment of the cycle. This fine-tuning of capital controls was necessary to maintain the volume of inflows needed to finance the current account deficit (the main macroeconomic constraint), then ensuring the maintenance of the exchange rate anchor (the macroeconomic regime). In this setting, the institutional features of the Brazilian financial system added challenges to the CAR strategy (see Table 3).

Given the middling financial openness and middle to high level of domestic financial market sophistication, foreign investors constantly succeeded in detecting ways to circumvent the capital inflow controls in order to invest in high-yielding public bonds, as stated also by the literature on capital controls in Brazil during this period. Thus, over the boom phases of the international capital flows cycle, the central bank continuously had to further broaden controls in order to cover existing regulation gaps. For example, to cope with swelling inflows, the financial tax was first extended to a broad range of capital inflows in March 1994, and then raised in October of the same year. In other words, CAR continuously had to be revised within a regulatory arbitrage cat-and-mouse game between regulators and international investors. ${ }^{5}$ Yet it is important to notice that this game repeatedly came to an end when that cycle entered a bust phase. Accordingly, the two moments of loosening capital controls during this period are related to the contagion effects of the Mexican financial crisis at the beginning of 1995, and the so-called Asian crisis of 1997 (see Table 2). In the face of the high external vulnerability and the inevitable depletion of international reserves, a currency crisis broke out in January 1999, resulting in the collapse of the exchange rate anchored macroeconomic regime.

5. For a detailed description of the financial strategies used by financial market players to avoid capital controls in Brazil during the 1990s, see Cardoso/Goldfajn (1997) and Carvalho/Garcia (2006). 


\section{CAPITAL ACCOUNT REGULATION IN BRAZIL: THE CASE OF THE 2000s}

As in the last section, we start with a review of the literature on CAR implemented in Brazil during the 2000s, which also focuses on the effectiveness of this regulation, disregarding the macroeconomic and institutional contexts. Thereafter, we undertake a qualitative assessment of the design of CAR in such a period, taking into account the macroeconomic regime in force.

\subsection{The literature review}

There are some empirical studies evaluating the effectiveness of the Brazilian CAR and foreign exchange derivatives regulations (FXDRs) over 2009-2012. Based on an econometric model (a generalized autoregressive conditional heteroskedasticity (GARCH) regression), Baumann/ Gallagher (2012) have found that the introduction of CAR in Brazil between October 2009 and December 2012 was associated with a shift from short-term to longer-term inflows. They have also found that Brazil's measures had a lasting impact on the level and volatility of the exchange rate and modestly increased the autonomy of Brazilian monetary policy.

Chamon/Garcia (2013) conclude that the controls adopted by the Brazilian government were effective in the sense of creating distortions in the pricing of financial assets, that is, making the domestic assets more expensive, which is one of the goals of the controls. Therefore, controls were effective in partially segmenting the Brazilian financial market from the international market. However, the controls do not seem to have been effective in detering the appreciation of the BRL when capital inflows were strong, a stated objective of the Brazilian authorities. Yet the authors stressed that they 'cannot rule out, however, that the cumulative effect of the controls strengthened the effect of the large cut of the basic interest rate (Selic), by $5.25 \mathrm{bps}$, in depreciating the BRL since March 2012.'

Finally, Klein (2012) concludes that the Brazilian IOF was an episodic control on the capital inflows that did not temper the appreciation of the Brazilian currency; but the period covered in his study ended in 2010 , before the adoption of a broader set of regulations, as detailed in the next section (see Table 4).

\subsection{CAR in the context of dirty inflation targeting and lower external vulnerability}

After the 1999 currency crisis, Brazil adopted a new macroeconomic regime featuring a floating exchange rate and an inflation target policy. The change in the macroeconomic

Table 4 Literature survey: evaluation of effectiveness of 2000s CAR

\begin{tabular}{|c|c|c|c|}
\hline Authors & Capital flows & Exchange rate & $\begin{array}{l}\text { Monetary policy } \\
\text { autonomy }\end{array}$ \\
\hline Chamon/Garcia (2013) & - & $\begin{array}{l}\text { No direct impact, but } \\
\text { probably indirect }\end{array}$ & Increased \\
\hline $\begin{array}{l}\text { Baumann/Gallagher } \\
\text { (2012) }\end{array}$ & $\begin{array}{l}\text { Lengthens } \\
\text { maturity }\end{array}$ & $\begin{array}{l}\text { Lasting (but small) impact } \\
\text { on the level and volatility }\end{array}$ & $\begin{array}{l}\text { Modestly } \\
\text { increased }\end{array}$ \\
\hline Klein (2012) & - & No impact & - \\
\hline
\end{tabular}

Source: Authors' compilation.

6. It is worth mentioning that neither Baumann/Gallagher (2012) nor Chamon/Garcia (2013) consider the regulation of FX derivatives to be another kind of regulation distinct from capital controls and financial prudential regulation. 
stance was accompanied by a deepening of the process of financial opening in January 2000, when Resolution CMN no 2689 authorized the unrestricted access of non-resident investors to all segments of the domestic financial market, including the derivatives market. Luis Inácio Lula da Silva's (hereafter Lula) economic policies, beginning in January 2003, were marked by the continuity of this macroeconomic regime. ${ }^{7}$ Yet, in contrast to the previous period (1999-2002), it was implemented in an exceptionally favorable international context, featuring rising commodity prices and a boom of capital flows to emerging countries (Ocampo 2007).

In this setting, opting for a tight monetary policy under the conditions of high financial openness ensured the effectiveness of the inflation targeting policy through the appreciation of the Brazilian currency, but forced the monetary authorities to abandon any kind of target for the nominal exchange rate. The main determinant of the currency appreciation in this period was the derivative carry-trade operations fostered by the very high interest rate differential (see Figure 6). Contrary to the canonical carry trade through spot market operations (borrowing low interest rate currencies and lending high interest rate currencies), in the FX derivatives market the carry trade expresses itself as a bet which results in a short position in the funding currency and a long position in the target currency (Burnside et al. 2006; Gagnon/Chaboud 2007; Kaltenbrunner 2010).

The predominance of this kind of currency speculation strategy stemmed from the greater liquidity and depth of the FX futures market (that is, the organized segment of the FX derivatives market) in comparison with the FX spot market, fostered by foreign investors' unrestricted access to this segment since 2000. This sophistication of the Brazilian currency market rendered the FX futures market the locus of formation of the BRL/US\$

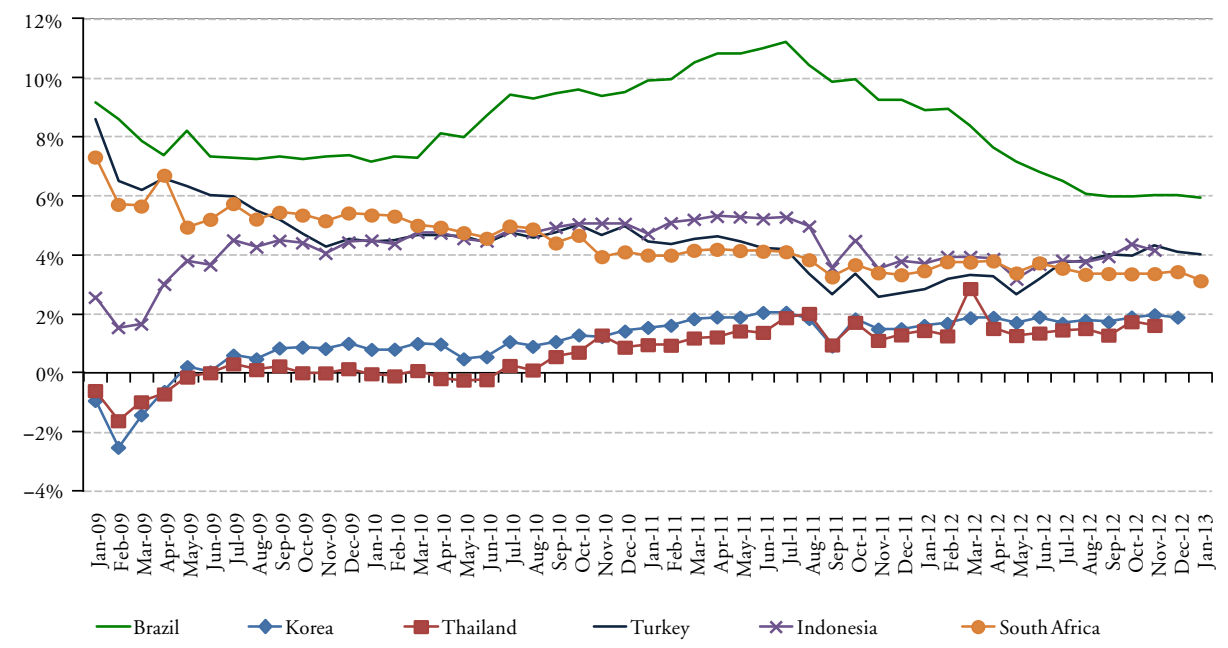

Note: a. Interest rate differential = country policy rate minus Fed Fund Rate plus country-risk. Sources: BCB; authors' compilation.

\section{Figure 6 Interest rate differential: ${ }^{\mathrm{a}}$ Brazil and other emerging economies}

7. The Brazilian economy became fully open to capital inflows and outflows in Lula's first term: in 2005, residents' capital exports were fully liberalized; and, in 2006, returns of government bonds owned by foreign investors were exempted from income tax. For a comprehensive analysis of the process of Brazilian financial opening, see Paula (2011). 
exchange rate (Chamon/Garcia 2013; Kaltenbrunner 2010). Moreover, the non-deliverable feature of the Brazilian FX derivatives market (that is, operations are settled in BRL, the only legal tender in the country) has made the derivatives carry trade even more attractive in Brazil, inasmuch as foreign and domestic agents can engage in it without disbursing a single US dollar (Fritz/Prates 2014).

At the same time, like many other emerging economies, Brazilian policy-makers adopted the strategy of paying off the public external debt and building up international reserves which aimed at strengthening the country's external position, the so called 'precautionary demand' for reserves (Aizenman et al. 2004; Carvalho 2010; Dooley et al. 2005). ${ }^{8}$ As Rodrik (2006: 12) points out, over the international capital flows boom before the global financial crisis, these countries 'over-invested in the costly strategy of reserve accumulation and under-invested in capital account management policies.'

Therefore, when the new cycle of capital flows to emerging economies surged after the 2008 global financial crisis (Akyüz 2011), Brazil did enjoy a rather low level of external vulnerability. Over the boom of the cycle, the country was one of the main destinations of short-term portfolio investments (IMF 2011) and suffered strong currency appreciation pressures from 2009 to mid 2011. This was due to a set of encouraging domestic factors: (i) the fast economic recovery; (ii) the post-crisis commodity price boom; (iii) a very high interest rate differential in comparison to other emerging economies (Figure 6); and (iv) the opportunity for high return through derivatives carry trade in the Brazilian futures exchange. Once again, foreign investors made one-way bets on the appreciation of the Brazilian currency through short positions in the FX futures market (selling US dollars and buying BRL - see Figure 7).

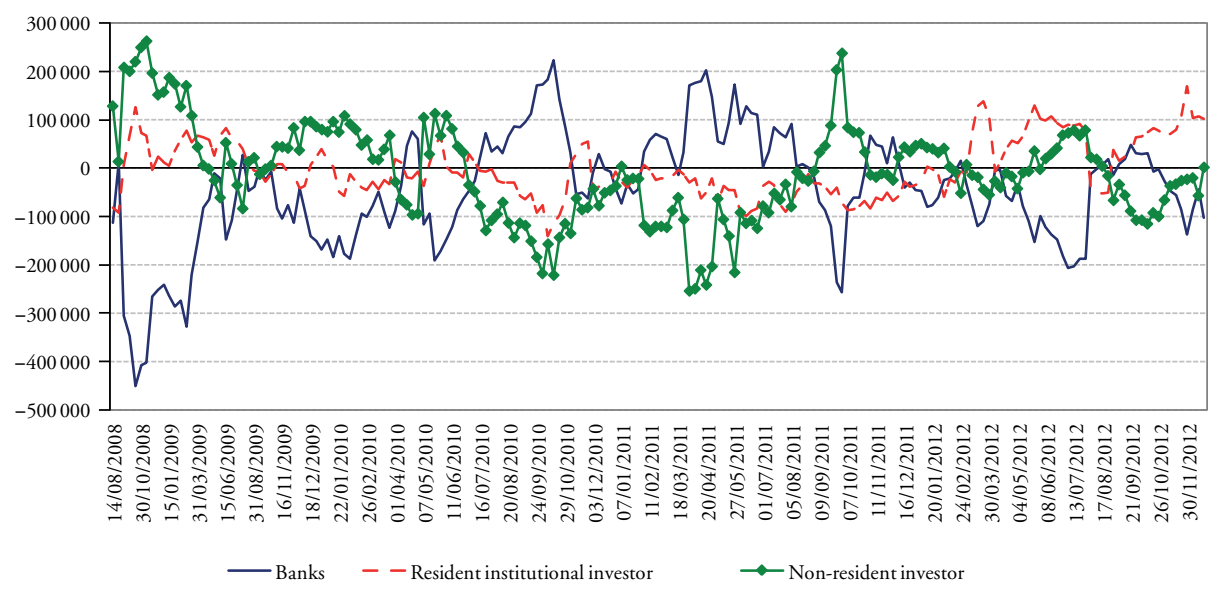

Note: a. Positive values means short BRL/long US\$ positions (bets on BRL depreciation) and negative values long BRL/short US\$ positions (bets in BRL appreciation).

Sources: BMFBovespa; authors' compilation.

\section{Figure 7 Investors' net positions in FX futures (number of USD futures contracts) ${ }^{a}$}

8. During this period the Brazilian monetary authority pursued a strategy of intervention in the FX market known as 'leaning against the wind' (Archer 2005), which attempted to reduce the exchange rate volatility without influencing the exchange rate trend. Yet this strategy resulted in an excessively high cost of sterilization operations due to the large differential between internal and external interest rates (Prates et al. 2009). 
Nevertheless, contrary to the pre-crisis context, Brazil did not adopt a hands-off approach to capital inflows. The government gradually moved towards a macroeconomic strategy where preventing currency appreciation gained relevance alongside the priority of inflation stabilization. This appreciation became an increasing concern due to its adverse impact on Brazilian industrial competitiveness which has faced much greater competition both in the international and domestic markets in the post-crisis setting. The introduction of CAR with the explicit goal of curbing the appreciation trend of the BRL, yet without giving up the formal strategy of inflation targeting, led to what we call 'dirty inflation targeting' - where the exchange rate goal gained increasing room in the definition of the macroeconomic policy strategy.

In October 2009 the Brazilian government adopted a light price-based capital control measure (see Table 5, overleaf), which was insufficient to curb the currency appreciation trend (Figure 8, p. 329). Within this macroeconomic setting, the aim was clearly different from the 1990s, as the statement of Finance Minister Guido Mantega on 21 October 2009 (the day after the first control was announced) clarifies: 'We want to prevent an excessive appreciation of the real. When the real appreciates, it makes our exports more expensive and our imports cheaper, and we already have an expressive increase in imports while the exports are not growing as they should' (cited in Chamon/Garcia 2013: 7).

The specific features of the Brazilian financial market, mainly the key role of the FX derivatives market on the exchange rate determination, as mentioned above, confronted Brazilian policy-makers with greater challenges to curb the currency appreciation than those faced by other emerging economies The Brazilian regulatory authorities recognized these constraints, albeit tardily. From October 2010 to the end of 2012 they implemented, along with capital controls, prudential financial regulations and FXDRs which apply to the FX derivatives operations of all agents, be they non-residents or residents, financial or non-financial actors (see Table 5).

This third class of regulation technique was key in restraining the BRL appreciation trend and, in turn, mitigating the Brazilian government's economic policy dilemma regarding how to contain the growth rate and inflationary pressures without reinforcing exchange rate appreciation. On the one hand, as FX derivatives are non-deliverable, capital controls do not reach them (the derivative carry trade could be put in place without any effective foreign currency flows). On the other hand, in the face of the predominance of FX futures, prudential financial regulation also proved insufficient to reach FX derivatives operations, as it did not encompass non-resident investors and non-financial resident agents.

In October 2010, along with the strengthening of the price-based capital control on portfolio investment, the Brazilian government launched the first FXDR (see Table 5). However, the first rounds of capital controls and FXDR proved insufficient to halt the BRL/US\$ exchange rate down trend (that is, BRL appreciation - see Figure 8). This is because private agents again found loopholes to circumvent these controls, similar to the process during the 1990s; moreover, FXDR were too lightweight to stem the derivatives carry trade, due to the latter's high degree of leverage. In order to close the loopholes, the Brazilian Central Bank imposed a non-interest reserve requirement (a prudential financial regulation) on FX banks' positions in January 2010 and an IOF on short-term foreign borrowing in March. However, private agents were able to make longer-term loans in the context of excess of liquidity and searching for yield in the international financial market (Figure 9, p. 329). Hence in April the government extended the IOF both to this class of foreign loans and to intercompany loans, which is one modality of foreign direct investment (FDI) that had also been used as a way of bypassing CAR (see Table 5).

Yet, until the first half of 2011, the CAR and FXDR adopted so far mainly impacted the composition of inflows rather than their volume and did not stop the BRL appreciation, its main policy goal (see Figures 8 and 9). As for the currency appreciation trend, the turning 
Table 5 Capital account regulation, 2009-2012

\begin{tabular}{|c|c|c|c|}
\hline Date & $\begin{array}{l}\text { Number } \\
\text { and kind }\end{array}$ & $\begin{array}{l}\text { Tighten or } \\
\text { loosen }\end{array}$ & Measure \\
\hline Oct. 2009 & 1 st $\mathrm{CC}$ & Tighten & $\begin{array}{l}\text { Implementation of a } 2 \% \text { financial transaction tax } \\
\text { (IOF) on non-resident equity and fixed income } \\
\text { portfolio inflows }\end{array}$ \\
\hline Oct. 2010 & 2nd CC & Tighten & $\begin{array}{l}\text { (i) IOF increased from } 2 \text { to } 4 \text { percent for fixed } \\
\text { income portfolio investments and equity funds } \\
\text { (ii) IOF increased to } 6 \text { percent for fixed income } \\
\text { investments }\end{array}$ \\
\hline Oct. 2010 & 1st FXDR & Tighten & $\begin{array}{l}\text { (i) IOF on margin requirements on FX derivatives } \\
\text { transactions increased from } 0.38 \text { to } 6 \text { per cent } \\
\text { (ii) Loopholes for IOF on margin requirements closed }\end{array}$ \\
\hline Jan. 2011 & 1st PR & Tighten & $\begin{array}{l}\text { Non-interest reserve requirement equivalent to } \\
60 \text { percent of bank's short dollar positions in the } \\
\text { FX spot market that exceed US\$ } 3 \text { billion or their } \\
\text { capital base }\end{array}$ \\
\hline Mar. 2011 & 3rd CC & Tighten & $\begin{array}{l}\text { Increased to } 6 \text { percent the IOF on new foreign loans } \\
\text { with maturities of up to a year }\end{array}$ \\
\hline Apr. 2011 & 4th CC & Tighten & $\begin{array}{l}\text { (i) } 6 \text { percent IOF extended for the renewal of foreign } \\
\text { loans with maturities of up to a year } \\
\text { (ii) } 6 \text { percent IOF extended for both new and renewed } \\
\text { foreign loans with maturities of up to } 2 \text { years }\end{array}$ \\
\hline Jul. 2011 & 2nd PR & Tighten & $\begin{array}{l}\text { Non-interest reserve requirement mandatory for } \\
\text { amounts over US\$ } 1 \text { billion or capital base } \\
\text { (whichever is smaller) }\end{array}$ \\
\hline Jul. 2011 & 2nd FXDR & Tighten & $\begin{array}{l}\text { Excessive long positions on BRL off all agents pay a } \\
\text { financial tax of } 1 \text { percent. This tax can be increased } \\
\text { up to } 25 \text { per cent }\end{array}$ \\
\hline Dec. 2011 & 5th CC & Loosen & $\begin{array}{l}\text { IOF on equity and fixed income (linked with } \\
\text { infrastructure projects) portfolio inflows reduced } \\
\text { to } 0 \%\end{array}$ \\
\hline Mar. 2012 & 6th CC & Tighten & $\begin{array}{l}\text { (i) } 6 \text { percent IOF extended for both new and renewed } \\
\text { foreign loans with maturities of up to } 3 \text { and then to } \\
5 \text { years } \\
\text { (ii) Export advanced payment transactions with } \\
\text { maturities of more than a year prohibited }\end{array}$ \\
\hline Mar. 2012 & 3rd FXDR & Loosen & Exporters hedge operations exempted from the IOF \\
\hline Jun. 2012 & & Loosen & $\begin{array}{l}6 \text { percent IOF only for new and renewed foreign } \\
\text { loans with maturities of up to } 2 \text { years }\end{array}$ \\
\hline Dec. 2012 & 8th CC & Loosen & $\begin{array}{l}\text { (i) } 6 \text { percent IOF for foreign loans with maturities of } \\
\text { up to } 1 \text { year } \\
\text { (ii) Export advanced payment transactions maturity } \\
\text { extended from } 1 \text { for } 5 \text { years }\end{array}$ \\
\hline
\end{tabular}

Note: a. $\mathrm{CC}$ = capital control; $\mathrm{PR}$ = prudential regulation; $\mathrm{FXDR}$ = foreign exchange derivatives regulation. Source: Authors' elaboration based on BCB's and Minister of Finance's websites.

point was in July, when a broader set of FX derivatives regulations was launched. On 29 July 2011, the Ministry of Finance adopted a financial tax of 1 percent on excessively long positions on BRL in the FX derivatives market (see Table 5). As this tax is calculated on the notional value of the FX derivatives operations, it had a major impact on the derivatives 


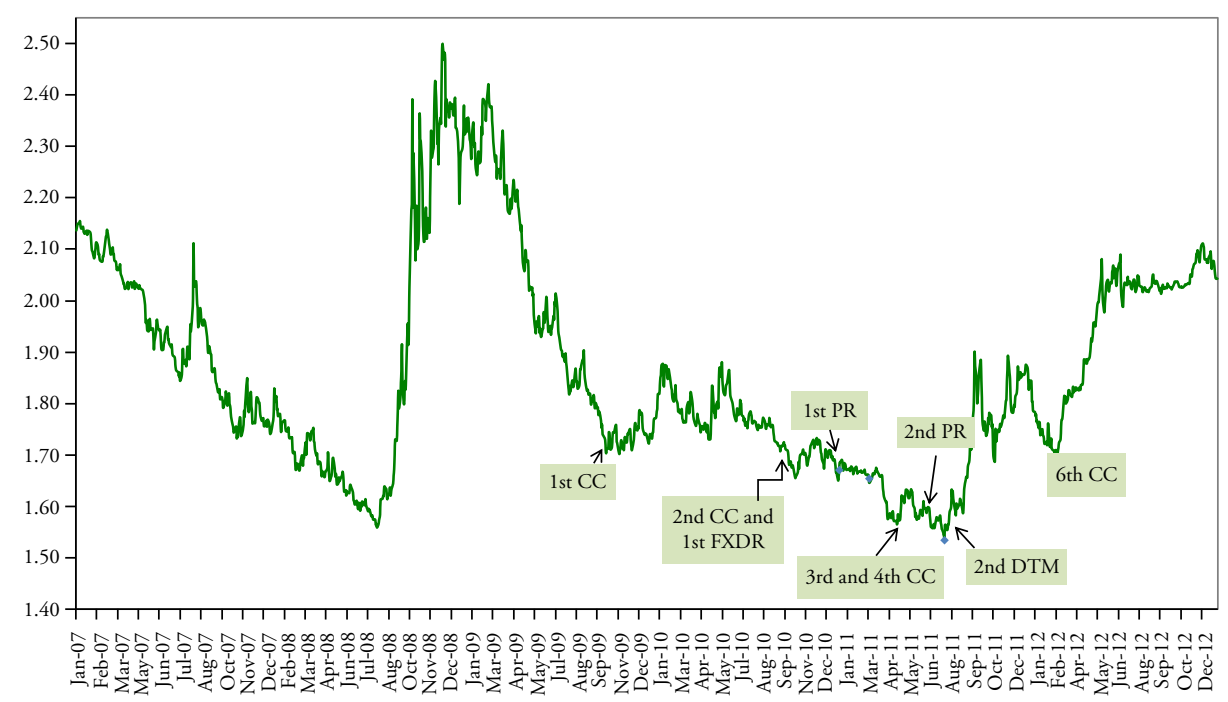

Sources: BCB; authors' compilation.

Figure 8 Brazil: BRL-US\$ exchange rate (nominal) and tighter regulations applied

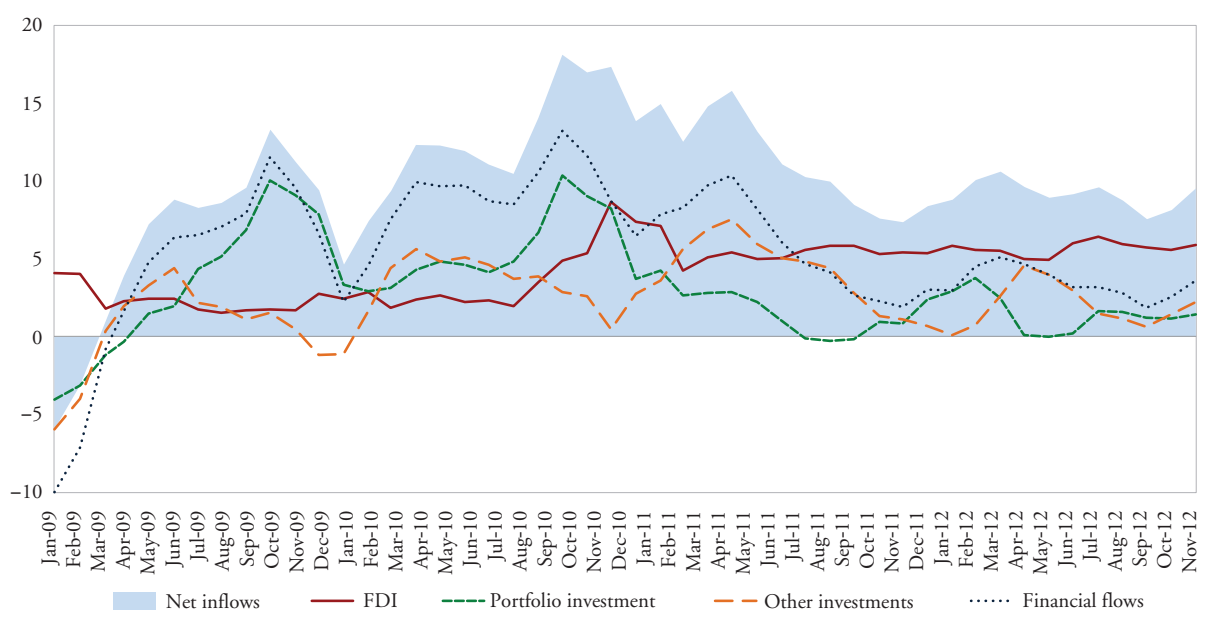

Sources: BCB; authors' compilation.

Figure 9 Net inflows - 3-month average, US\$ billion

carry trade. Shortly after this was enforced, the Brazilian currency began depreciating, prior to the loosening of the monetary policy in August (see Figure 8). Since the end of August, the depreciation trend was fostered by the policy rate reductions (Figure 6) and the increase in the risk aversion of foreign agents due to the worsening of the euro crisis in the second half of 2011.

Hence, despite the higher financial openness and financial market sophistication, in a setting of eased macroeconomic constraints (mainly, the lower external vulnerability), the 
Table 6 Brazil, 2000s

Macroeconomic constraints

- FX higher than external debt, but current account deficit increasing

- Moderated inflation

\begin{tabular}{l|l}
\hline \multicolumn{2}{c}{ Macroeconomic regime } \\
\hline $\begin{array}{l}\text { Macroeconomic policy } \\
\text { Dirty inflation targeting }\end{array}$ & Institutions \\
Aim: inflation control with priority also to real & \\
exchange rate (RER) & \\
Target: inflation and nominal exchange rate & \\
Tools: & \\
- Monetary and exchange rate policy & - Financial openness: high \\
- CAR & - Financial market sophistication: \\
Aim: halt currency appreciation & high (derivatives) \\
Target: reduce volume of short-term capital inflows \\
Tools: price-based capital controls (financial tax), \\
administrative controls, prudential regulation, \\
expansion to regulation of FX derivatives => \\
comprehensive regulation
\end{tabular}

Source: Authors' compilation.

Brazilian government had the policy space to launch a broader class of regulations to reach the aims of the macroeconomic regime in force (see Table 6). ${ }^{9}$ Moreover, there are feedback effects between these regulations and the macroeconomic policies. The FXDR may have amplified the effects of the policy rate drops between August 2011 and October 2012 on the BRL/US\$ exchange rate. In this new external and domestic setting (lower policy rate and stable exchange rate, and broad regulatory framework), both financial flows and derivatives carry trade operations dwindled (Figures 7 and 9).

\section{COMPARATIVE ANALYSIS}

The dominant literature for the Brazilian case of capital controls in the 1990s concludes that the effectiveness of capital controls might be limited in an environment where the sophistication of the financial markets reduces the cost of circumvention in view of the persistent incentives provided by interest rate differentials (see Section 3.1). In turn, most of the empirical literature in the 2000s shows that the regulations adopted during 2009-2011 (CAR and FXDRs) had some effectiveness in changing the composition of capital flows and curbing currency appreciation despite the greater sophistication and openness of the Brazilian financial market and the still-high interest rate differential (see Section 4.1).

9. The Brazilian government has had the policy space to engage in such a broad regulatory framework because it does not have trade and investment treaties or commitments under the General Agreement on Trade in Services (GATS) that prohibit the regulation of capital flows and FX derivatives (Paula/Prates 2013). 
Our comparative perspective of Brazil's experience with CAR in the 1990s and 2000s is not focused on effectiveness, but on the design of the CAR (see Sections 3.2 and 4.2). Comparing the two periods of CAR in Brazil, we find that the overall macroeconomic regime is highly relevant for its design, along with the macroeconomic constraints and the features of the domestic financial market, especially its level of openness and sophistication. While the macroeconomic regime and the macroeconomic constraints frame the aims and, consequently, targets of the CAR, the features of the domestic financial market shape the specific tools that will be put in place to achieve these aims.

During the 1990s, the macroeconomic regime gave absolute priority to inflation stabilization. In order to combat four-digit inflation, an exchange rate anchor was combined with a huge interest rate differential to attract permanent capital inflows. These inflows were required not only to build up international reserves (a precondition for the maintenance of that anchor), but also to finance the growing external commitments (cumulative current account deficit and high external debt to be served).

In this setting of still-high external vulnerability, the main aim of the CAR was to change the composition of capital inflows from short-term to long-term inflows, that is, to lengthen their maturity. In an international context of highly volatile capital flows and a middle level of financial openness, capital controls had to be adjusted together with domestic policies taking into account the availability of international inflows. In moments of excessive inflows, controls were introduced or intensified to curb their volume so as to avoid overburdening the fiscal cost of sterilization (a consequence of the very interest rate differential), and were accordingly relaxed in periods of drying capital inflows. Therefore, the only tool adopted was capital controls (one class of CAR). The institutional features of the financial market in the 1990s played a role in the design of the specific capital controls. For instance, in a context of mid-level sophistication of this market, some administrative controls were adopted to close the loopholes found by private agents to circumvent the regulations aimed at curbing short-term financial flows. The CAR could not be broader (which would guarantee its effectiveness according the literature summarized in Section 2), as the maintenance of the macroeconomic regime depended on continuous capital inflows, yet of longer maturity in the face of high external vulnerability.

In contrast, in the context of the new boom of capital flows towards emerging markets after the global financial crisis, specifically, during 2009-2011, the Brazilian government gradually moved towards a macroeconomic strategy where preventing currency appreciation gained relevance alongside the priority of inflation stabilization under a macroeconomic regime featuring a dirty floating exchange rate and an inflation target policy. In order to untie the exchange rate and interest rate movements and achieve these aims in conditions of low external vulnerability, policy-makers gave increasing relevance to CAR.

Yet the new institutional features of the Brazilian financial market required the adoption of a more comprehensive set of CARs. This had to encompass not only capital controls on inflows (as in the 1990s), but also financial prudential regulations. Furthermore, due to the key role of the FX derivatives markets in the determination of the exchange rate, another class of regulation needed to be adopted, the FXDR. Hence our analysis of the Brazilian case shows that the higher the degree of sophistication and financial openness of the domestic financial market, the higher are the requirements for a more active and comprehensive regulation to reach the aims of the macroeconomic regime.

\section{CONCLUSION}

Following the plea from Dani Rodrik that we have to learn more about capital account regulation (CAR), in this paper we focus on the context in which these measures are adopted. We 
argue that most literature until now has discussed technical aspects of CAR and its efficiency, overseeing its strong dependency on the broader economic setting of a country. Using the concept of macroeconomic regime, we bring to light firstly the interdependency between macroeconomic constraints and the macroeconomic regime, and between macroeconomic policy, the institutional framework and CARs. Indeed, the understanding of how these regulations are designed is key to evaluating their performance and, hence, potential efficiency.

To test this, we chose to compare the regulation of capital flows within one country in two different periods, where at the technical level rather similar CARs were applied, but had different designs especially regarding aims and targets, due to strongly differing macroeconomic regimes and macroeconomic challenges. With the exchange rate playing the main role of inflation stabilization, for instance, stabilization of capital inflows has to be the major policy goal, so that CAR cannot aim at reducing these inflows. Even less regarded in the literature is the state of external vulnerability, which again strongly influences whether CAR can be oriented towards reducing the volume of inflows or only towards a lengthening of their maturities. The comparison of two periods in Brazil also demonstrates that institutional features of the financial market - mainly, its degree of sophistication and openness - shape the specific tools to be put in place to achieve these aims.

This analytical framework on the design of CAR is an important complement to econometric studies on its effectiveness. We expect similar variables to be key for their design in other cases. To test for their robustness, however, further studies have to be undertaken, such as research design of single case studies or comparative analysis among the group of emerging market countries. We leave this to future research.

\section{REFERENCES}

Aizenman, J., Lee, Y., Rhee, Y. (2004): International reserves management and capital mobility in a volatile world: policy considerations and a case study of Korea, NBER Working Paper No 10534.

Akyüz, Y. (2011): Capital flows to developing countries in a historical perspective: will the current boom end with a bust and how?, South Centre Research Paper 37.

Archer, D. (2005): Foreign exchange market intervention: methods and tactics, BIS Papers, No 24.

AREAER (various issues): Annual report on exchange arrangements and exchange restrictions, Washington, DC: International Monetary Fund.

Ariyoshi, A., Habermeier, K., Laurens, B., Otker-Robe, I., Canales-Kriljenko, J.I., Kirilenko, A. (2000): Capital controls: country experiences with their use and liberalization, IMF Occasional Papers, No 190.

Baumann, B., Gallagher, K.P. (2012): Navigating capital flows in Brazil and Chile, Initiative for Policy Dialogue Working Paper Series, June.

BIS (2005): Foreign exchange market intervention in emerging markets: motives, techniques and implications, BIS Papers, No 24, May.

BCB (Brazilian Central Bank) (various issues): Boletim do Banco Central - Relatório anual.

Blumenschein, F., Guinle, A.C.C. (2001): Liberalizaçáo financeira no Brasil 1990-2000: revisão da literatura, fatos e implicaçôes, mimeo, São Paulo: IBRE/FGV.

Burnside, C., Eichenbaum, M., Kleshchelski, I., Rebelo, S. (2006): The returns of currency speculation, National Bureau of Economic Research, Working Paper No 12489.

Calvo, G.A., Leiderman, L., Carmen, M., Reinhart, C.M. (1993): Capital inflows and real exchange rate appreciation in Latin America: the role of external factors, in: IMF Staff Papers, 40(1), 108-151.

Cardoso, E., Goldfajn, I. (1997): Capital flows to Brazil: the endogeneity of capital controls, IMF Working Paper, No 97/115.

Carvalho, F.C. (2010): The accumulation of international reserves as a defense strategy, in: GriffithJones, S., Ocampo, J.A., Stiglitz, J.E. (eds), Time for a Visible Hand: Lessons from the 2008 World Financial Crisis, Oxford: Oxford University Press, 269-284. 
Carvalho, B.S. de M., Garcia, M.G. (2006): Ineffective controls on capital inflows under sophisticated financial markets: Brazil in the nineties, NBER Working Paper, No 12283, URL: http:// www.nber.org/papers/w12283.

Chamon, M., Garcia, M. (2013): Capital controls in Brazil: effective? PUC Rio de Janeiro, Discussion Paper, No 606.

De Gregorio, J., Edwards, S., Valdés, R.O. (2000): Controls on capital inflows: do they work?, in: Journal of Development Economics, 63(1), 59-86.

Dooley, M. (1996): A survey of literature on controls over international capital transactions, in: IMF Staff Papers, 43(4), 639-687.

Dooley, M., Folkerts-Landau, D., Garber, P. (2005): International financial stability, Report, Deutsche Bank, Global Markets Research, October, URL: http://people.ucsc.edu/ mpd/ InternationalFinancialStability_update.pdf.

Edwards, S. (1999): How effective are capital controls?, in: Journal of Economic Perspectives, 13(4), 65-84 (cited from the internet version, URL: http://www.anderson.ucla.edu/faculty/sebastian. edwards/controls_final.pdf).

Fettig, D. (1996): Interview with James Tobin, Federal Reserve Bank of Minneapolis, in: The Region, 1 December, URL: http://bit.ly/VpqsgL.

Franco, G., Pinho, D. (2004): A desregulamentação da conta de capitais: limitaçôes macroeconômicas e regulatórias, PUC Rio de Janeiro, Discussion Paper, No 479.

Fritz, B. (2000): Development or growth-cum-debt? Reflections on Latin America's economic strategy in a time of international financial instability, Freie Universität Berlin, Discussion Paper, No 2000/10.

Fritz, B., Prates, D.M. (2014): The new IMF approach to capital account management and its blind spots: lessons from Brazil and South Korea, in: International Review of Applied Economics, 28(3), 210-239.

Gagnon, J.E., Chaboud, A.P. (2007): What can the data tell us about carry trades in Japanese yen? Board of Governors of the Federal Reserve System, International Finance Discussion Papers, No 899.

Gallagher, K., Griffith-Jones, S., Ocampo, J.A. (eds) (2012): Regulating Global Capital Flows for Long-Run Development, Boston: Pardee Center Task Force Report.

Garcia, M.G., Barcinsky, A. (1997): Capital flows to Brazil in the nineties: macroeconomic aspects and the effectiveness of capital controls, PUC Rio de Janeiro, Discussion Paper, No 357.

Herr, H., Kazandziska, M. (2011): Macroeconomic Policy Regimes in Western Industrial Countries, London: Routledge.

IMF (2011): Recent experiences in managing capital inflows: cross-cutting themes and possible policy framework, URL: http://bit.ly/QSqrVQ.

IMF (2012): The liberalization and management of capital flows: an institutional view, URL: http://www.imf.org/external/np/pp/eng/2012/111412.pdf.

Kaltenbrunner, A. (2010): International financialization and depreciation: the Brazilian real in the international financial crisis, in: Competition and Change, 14(3-4), 294-321.

Klein, M.W. (2012): Capital controls: gates versus walls, in: Brookings Papers on Economic Activity, URL: http://www.brookings.edu/ //media/Projects/BPEA/Fall\%202012/2012b_Klein.pdf.

Kregel, J. (2000): The Brazilian crisis: from inertial inflation to fiscal fragility, Levy Institute, Working Paper, No 294, URL: http://www.levyinstitute.org/pubs/wp294.pdf.

Magud, N., Reinhart, C.M., Rogoff. K. (2011): Capital Controls: Myth and Reality - A Portfolio Balance Approach, Cambridge, MA: National Bureau of Economic Research.

Ocampo, J.A. (2007): La macroeconomia de la bonanza económica latinoamericana, in: Revista de la Cepal, 93, 7-29.

Ostry, J., Ghosh, A., Habermeier, K., Chamon, M., Qureshi, M., Reinhardt, D. (2010): Capital inflows: the role of controls, IMF Staff Position Note, No 10/04.

Paula, L.F. de (2011): Financial Liberalization and Economic Performance: Brazil at Crossroads, London: Routledge.

Paula, L.F. de, Prates, D.M. (2013): Capital account regulation, trade and investment treaties and policy space in Brazil, in: Gallagher, K., Stanley, L. (eds), Capital Account Regulations and the Trading System: A Compatibility Review, Boston: Frederick S. Pardee Center for the Study of Longer-Range Future, 55-67. 
Paula, L.F. de, Oreiro, J.L., Silva, G.J. C. da (2003): Fluxos e controle de capitais no Brasil: avaliação e proposição de política, in: Sicsú, J., Oreiro, J.L., Paula, L.F. de (eds), Agenda Brasil: políticas econômicas para o crescimento com estabilidade de preços, Barueri/São Paulo, Editora Manole, 65-116.

Prates, D.M., Cunha, A.M., Lélis, M.T.C. (2009): Exchange rate management in Brazil, in: ECLAC Review, 99, 97-118.

Reinhart, C., Smith, T. (1998): Too much of a good thing: the macroeconomic effects of taxing capital inflows, in: Glick, R. (ed.), Managing Capital Flows and Exchange Rates: Perspectives from the Pacific Basin, Cambridge, UK: Cambridge University Press, 436-464.

Rodrik, D. (2006): The social cost of foreign exchange reserves, in: International Economic Journal, 20(3), 253-266.

Rodrik, D. (2010): The end of an era in finance? in: Project Syndicate, URL: http://bit.ly/XuxYxl.

Singh, A., Belaisch, A., Collyns, C., De Masi, P., Krieger, R., Meredith, G., Rennhack, R. (2005): Stabilization and reform in Latin America: a macroeconomic perspective of the experience since the 1990s, IMF Occasional Paper, No 238, URL: http://www.imf.org/external/pubs/ft/op/238/ index.htm.

Williamson, J., Griffith-Jones, S., Gottschalk, R. (2003): Should capital controls have a place in the future international monetary system? Mimeo, URL: http://bit.ly/12h2wlK (accessed 10 December 2012).

World Bank (2001): Finance for growth: policy choices in a volatile world, World Bank Research Report, Washington, DC: Oxford University Press.

\section{FURTHER READING}

Baele, L., Bekaert, G., Cho, S., Koen, I., Moreno, A. (2011): Macroeconomic regimes, NBER Working Paper, No 170.

Eichengreen, B., Hausmann, R. (eds) (2005): Other People's Money: Debt Denomination and Financial Instability in Emerging Market Economies, Chicago: University of Chicago Press.

Farhi, M. (2010): (Os) impactos dos derivativos no Brasil, in: Marcolino, L.C., Carneiro, R. (eds), Sistema financeiro e desenvolvimento no Brasil, São Paulo: Atitude, 209-232.

Franco, G. (1995): O Plano Real e outros ensaios, Rio de Janeiro: Francisco Alves.

Gallagher, K. (2014): Countervailing Monetary Power: Emerging Markets and the Re-Regulation of Cross-Border Finance, Ithaca, NY: Cornell University Press.

Kaltenbrunner, A., Painceira, J.P. (2012): The Impossible Trinity on 'Steroids': Inflation Targeting and Exchange Rate Management in Emerging Markets, Leeds University Business School, unpublished manuscript.

Rey, H. (2013): Dilemma not Trilemma: The Global Financial Cycle and Monetary Policy Independence, Jackson Hole Symposium, London: London Business School, CEPR and NBER. 